\title{
Constraints in the Implementation of Digital Ethics in SMA Muhammadiyah 1 Surakarta
}

\author{
Roni Yudo Kuncoro ${ }^{1}$, Triyanto $^{2}$, Rini Triastuti $^{3}$ \\ ${ }^{1}$ Student of Post Graduate Civic Education Sebelas Maret University, Indonesia \\ ${ }^{2,3}$ Lecturer of Post Graduate Civic Education Sebelas Maret University, Indonesia \\ roniyudokuncoro@gmail.com
}

\begin{abstract}
Globalization has brought changes in all aspects of life in the political, economic, social or cultural fields. The purpose of this study is to determine the obstacles in the application of digital ethics. This study used descriptive qualitative method. Data sources used were informants (Citizenship Education Teachers and students). Data collection techniques used were interviews and observation. Analysis of the data used is interactive model data analysis. The steps of the research procedure are the preparation stage, the data collection stage, the data analysis stage, and the preparation stage. The results showed that some students who at the time of their teaching and learning activities did not pay attention to the teacher, because they were playing mobile phones when teaching and learning activities applications that were opened to male students more often open games, but for female students more often open social media. The teacher also has the right policy by giving strict sanctions in the form of punishment so that students have good ethics during teaching and learning activities.
\end{abstract}

Keywords

internet; ethics; civic education teachers

\section{Introduction}

Globalization has brought changes in all aspects of life in the political, economic, social or cultural fields. One reason for this change is the development of knowledge and technology. The existence of technology that is the internet where this technology has a major influence on the current era. Initially the internet was used in the military field, but now the internet has become one of the needs with the widespread use of computers and mobile phones (Kürşad Çağrı Bozkirlii, 2018). Lifestyle in this era is undergoing change with the use of the internet which provides comfort in the field of communication and in other fields, which impose new habits in today's society (Mehmet T, Orhan E, Adem T, 2010).

Based on data from the Secretary General of the Indonesian Internet Service Providers Association, Henri Kasyfi, said that in Indonesia, from a total population of 264 million people, 171.1 million people were connected to the internet or $64.8 \%$ of the population in Indonesia, this figure increased which in 2017 there is only $54.86 \%$, for the age of most internet accessers are in the age range of 15-19 years, therefore the contents on the internet need to be considered (https://tekno.kompas.com/).

Data related to Indonesian literacy levels in 2016, submitted by Central Connecticut State University, United States with data titled World's Most Literate Nations Ranking released on March 9, 2016. The study ranked Indonesia 60th out of a total of 61 countries studied (https: / /tirto.id).

The low literacy rating in Indonesia has an impact on the low quality of education in Indonesia. The learning Curve Pearson, a world education rating agency in May 2014 released data on the world education quality ranking. Indonesia sits in the last position out of 40 recorded countries with an overall rating of minus 1.84 . The phenomenon of the low level 
of literacy and quality of education in Indonesia is in contrast to the development of Information technology related to social media in Indonesia. On the world social networks like Instagram, Facebook, Path and so on, users from Indonesia rank in the top 10 biggest users of these sites (http://www.kompasiana.com).

Mulyasa argues (2008: 5), "Teachers have a strategic role in efforts to realize national development, especially in the field of education, so it needs to be developed as a professional and dignified professional". Iskandar (2010: 1) revealed, "The teacher is the spearhead of the ongoing teaching and learning process, so that the teacher has an important role as a source of learning in the transformation of the value of science".

Education has now been affected by globalization, which is now utilizing internet technology. The internet also has positive and negative impacts in the world of education. Where in teaching and learning activities can take advantage of the internet to facilitate the lessons being taught. But apparently the internet also has a dangerous negative impact including 209 patients who are addicted to playing mobile data in the West Java Provincial Hospital until now (https://www.tribunnews.com). Quoted from the republika National where in the city of Surakarta itself there was an increase in cellphone addiction, even in the last 3 months there were already 35 patients who went to the Solo RSJD.

Teaching and learning activities in the classroom does not hurt to use Information and Communication Technology even in the Minister of Education Regulation Number 16 of 2007 concerning Standards of Academic Qualification and Teacher Competence explains the Pedagogical Competence of a teacher in more detail for the level of SMP / MTs and SMA / MA / SMK which consists of 37 competencies are summarized in 10 core competencies, one of which is related to ICT is utilizing information and communication technology for learning purposes in accordance with Robinson Situmorang's theory (in Dewi Salma Prawiradilaga, et al, 2013: 20-21).

The influence of this addiction can be seen during class time where in various cases such as students who are playing cellphones without paying attention to teaching and learning activities in class (https://www.liputan6.com,), students who play cellphones and are reprimanded by their teachers but their teachers are persecuted (https://www.cnnindonesia.com).

This case shows related to the importance of ethics when teaching and learning activities take place, especially ethics in digital utilization. The importance of ethics in digital utilization is explained by Roberto L Suson (2019) who states that the existence of ethics in digital utilization can lead to responsible citizens. School digital citizenship is very important in providing responsible digital citizens. In addition, the stakeholders involved in the education system must be fully aware of the norms of responsible behavior relating to the use of technology and how to become responsible digital citizens or known as digital citizens.

\section{Research Method}

This research method, starting from 5-15 October 2019 and the place of research is SMA Muhammadiyah 1 Surakarta, the approach used in this study is a qualitative approach. By definition qualitative research is a research conducted to find out and understand phenomena about what is experienced by the research subject and is presented in the form of descriptive data in the form of written or oral words from people and observable behavior. This type of research is a qualitative descriptive study, because it describes the object being studied (people, institutions or others) based on facts. According to H, Sutopo stated that 
"Sources of data in qualitative research can be human, event, or activity, place or location, objects, various images, or records, documents or archives" (2002: 50-54), subjects are students and Muhammadiyah 1 High School teacher and object of study learning resources, data mining data analysis techniques: H. B Sutopo (2002: 91) states that "in the process of data analysis there are 4 main components that must be understood by every qualified researcher. The four components are: (1) data collection, (2) data reduction, (3) data presentation, (4) conclusion or verification ".

\subsection{Results}

\section{Discussion}

Researchers obtained data from interviews and observations by interviewing Civic Education teachers and students. From interviews conducted with Utami who is a Civic Education teacher at Muhammadiyah 1 Surakarta High School, it was found that the internet had both positive and negative impacts. The positive impact of the internet can facilitate us in obtaining information, but the internet also has negative impacts such as pornography and games that are not educational. According to Utami the teacher must know the internet as a source of learning, and the teacher must know which are positive and negative in order to supervise students when teaching and learning activities that utilize the internet so that students open the internet in accordance with the material being discussed. Utami often uses the internet as if in a book he did not open the internet to search for it. Usually what is opened is material in the form of documents, or videos that are suitable for learning. Utami in utilizing social media that is used is Facebook which is used to upload or download education-oriented examples such as motivation. For the constraint is if the students at the time of teaching and learning activities do not pay attention to the lesson, open the handphone without the teacher's permission, and open the handphone but do not match the material taught such as opening whatsapp, or game application. Punishment is certainly very necessary so students do not repeat this. According to Utami, what was done was to notify students in advance so that students in teaching and learning activities must comply with applicable regulations such as opening a cellphone if they get permission from the teacher, also if the material related to utilizing the internet students must open according to the direction of the teacher. Penalties will be given if students do not comply with this by confiscating the student's cellphone and then given to the student section of the school as evidence of violations when teaching and learning takes place. According to Utami this is effective in shaping students so that they have good character, and usually students who the sentence has been given will not repeat it again and provide an example for other friends so as not to commit the same violation.

Meanwhile, from observations made at this high school it was found that in each class there were rules which included respecting the teacher during the lesson. Furthermore, during teaching and learning activities when students are told to look for materials or materials related to ongoing lessons, there are some students who open the internet not in accordance with the subject matter for female students, usually they open social media while for male students they usually open games. Even teachers who know this provide strict sanctions for students who commit these violations, by confiscating mobile phones that are being used to play social media or play games. Furthermore, the teacher then hands over the cellphone to the students as evidence that the student has violated the discipline during teaching and learning activities. The punishment is done so that the student is deterrent and does not repeat it again, usually students who have their cellphones seized during the lesson will change 
attitudes for the better here ie they become more attentive to the lesson. Even this relates to the confiscation of a cellphone by the teacher which gives another positive impact, which is to give an example to other friends so that they pay attention to the teacher or do what the teacher tells them to do.

In connection with the reason students open social media during the lesson the researcher examined several students as explained by Sholeh where he just wanted to open it and was bored with the lesson. While the statement from Tiffany because she was bored, and because she was tired. Furthermore, as explained by interest who is a class XI student, he explained that he sometimes opens his cellphone during lessons because he is bored and sleepy, which is often opened, he is social media, namely Instagram and WhatsApp. Furthermore, there are also students who play mobile phones during lessons because the student turns out that during breaks he plays online games with his friends, so when the break is over he still continues to play games to finish the online games, sometimes there are also some students who play games with friends in the class because they want to achieve something in the game like running a mission event.

In connection with the student section is part of the school in charge of students which includes taking care of violations committed by students, teachers who have handed mobile phones to the student section of mobile phones will be confiscated according to the time of confiscation can take months depending on the violations committed by the student. The cellphone can be taken if the time of confiscation or punishment is over then the student can ask the family to take the handphone to do this to form the student's character so that it is better.

\subsection{Discussion}

Ethics are very important in our lives, in Javanese own language ethics is manners or politeness. Etymologically ethics comes from the Greek ethics and ethos, ethos has the meaning of nature, habits, and character. While ethikos has moral meaning, behavior, civilization (abd Haris: 2007). This opinion is strengthened by his opinion Rini and Intan (2015) which further explains ethics which states that ethics is a good living habit of a person, group or society that relating to the rules of life that are followed and passed down down. Based on Rini's opinion, Intan and also abd Haris can be interpreted that ethics is something that is needed to know what should be done by a person, group or society that is followed and passed down from generation to generation.

Meanwhile according to Istighfarotur Rahmaniya (2010) Ethics has the meaning of knowledge that discusses good and bad about human behavior. Whereas in kbbi.web.id $(1 / 3 / 2020)$ explains that ethics is a science of good and bad and about moral rights and obligations. Based on these two opinions, it can be interpreted that ethics is a knowledge of good and bad about human behavior and also about moral rights and obligations.

Ethics in Arabic is known by the term morality which means character while in Indonesian it is called moral conduct (Hasbullah: 1978). In id.wikipedia.org (accessed 3/1/2020) explains that ethics is very necessary to know what should be done with the concept of right, wrong, good, bad and also responsibility. Based on the opinion of Hasbullah and in Wikipedia it can be interpreted that ethics is a character that is needed by a person, group or society to know good, bad things, wrong and right as well as to know responsibility.

Based on the ethical opinions of some of the experts above, it can be concluded that ethics is an indispensable rule of life, good, bad, right, wrong and also responsibilities which are the habits of life of a group or society that is followed and passed down from generation 
to generation. Ethics is very important because with ethics we can know the wrong and right of something, good and bad about something, especially in learning done in class a teacher or student must have ethics so that learning in class can be effective and efficient.

Kasmir (2005) states that the general ethical provisions are as follows:
b. Appearance
c. How to dress
d. How to talk
e. Movement
f. How to ask

a. Attitudes and behavior

Kasmir's opinion, if it is related to the ethics in school, can be interpreted that at school both the school apparatus starts from the teacher and students or others starting from the attitude and behavior, appearance, how to dress, how to speak, gestures, and how to ask must be good and polite in order to create a harmonious atmosphere.

In this era, technology is getting more advanced and information can be obtained easily because now it is a digital era. Digital itself according to wikipedia.org (1/6/2020) is a depiction of a number of numbers 0 and 1 where all systems on a computer utilize a digital system as its database. Meanwhile according to Indrajit (2002) a website is a collection of digital information that can be accessed by anyone. Based on these two opinions, it can be interpreted that digital is a picture of a number on a computer system that can be a website, internet, cell phone, etc.

Whereas in education.vic.gov.au (accessed 1/6/2020) it is explained that Digital technology is an electronic device, system, device, and resource that produces, stores, or processes data. Famous examples include social media, online games, multimedia and cellphones. Digital learning is any type of learning that uses technology. This can occur in all areas of curriculum learning. Meanwhile digital according to encyclopedia.com (accessed $1 / 6 / 2020$ ) is as follows digital technology is a two basis process. Digitized information is recorded in binary code combinations of numbers 0 and 1, also called bits, which represent words and images. Digital technology allows large amounts of information to be compressed on small storage devices that can be easily stored and transported. Digitalization also accelerates the speed of data transmission. Digital technology has changed the way people communicate, study and work. Based on digital opinion according to education.vic.gov.au and also encyclopedia.com can be interpreted that digital is an electronic tool that can produce, store, process data or information.

Based on some diatan's opinions about digital, it can be concluded that digital is a computer system that can produce, store and process data. In this current era the education sector must have been affected by the digital world where the digital development has made it easier for effective and efficient learning.

Based on the theory above it can be seen that some students still do not have good ethics during teaching and learning activities because they open their cellphones during teaching and learning activities. This is certainly if left unchecked will not be good for students. Some students when they open the application in the form of games for male students while for female students more often create social media such as whatapp, Instagram or other social media such as Facebook even though judging from the current news and based on expert opinion above can be known that the game or social media if used is not according to the rules or can be overblown then this will be dangerous for students for example is an addiction which if left unchecked will interfere with student health problems both physical or 
spiritual health. The teacher also has the right policy to impose strict sanctions in the form of punishment so that students have good ethics during teaching and learning activities for example by confiscating mobile phones where this seems to have a good impact on students who apparently students who initially paid less attention because he was busy playing mobile phones now become more active in teaching and learning activities and other positive effects that can be seen is this matter about giving examples to other students so that in teaching and learning activities students must have good ethics.

\section{Conclusions}

The obstacle of applying digital ethics in the Muhammadiyah 1 Surakarta high school is where there are some students who when teaching and learning activities they do not pay attention to the teacher, because they play mobile phones when teaching and learning activities applications that are opened on male students more often open games, but for female students more often open to social media. The teacher also has the right policy to impose strict sanctions in the form of punishment so that students have good ethics during teaching and learning activities, for example by confiscating mobile phones where this seems to have a good impact on students who apparently students who initially paid less attention because he was busy playing mobile phones now become more active in teaching and learning activities and other positive effects that can be seen is this matter about giving examples to other students so that in teaching and learning activities students must have good ethics.

\section{References}

Mehmet Tekerek, Orhan Ercan, Adem Tekerek.(2011). A descriptive study about internet use attitudes of physics teachers. Procedia Social and Behavioral Sciences, 15 (2011), 3758-3762. doi:10.1016/j.sbspro.2011.04.369

Kürşad Çağrı Bozkirlii.(2018). Examination Of Educational Internet Usage Self-Efficacy Beliefs Of Turkish Teacher Candidates. European Journal of Open Education and Elearning Studies, 3 (2), 32-42. doi: 10.5281/zenodo.1450670

Yudha Pratomo. (16 May 2019). Jumlah Pengguna Internet di Indonesia Tembus 171 Juta Jiwa.https://tekno.kompas.com/read/2019/05/16/03260037/apjii-jumlah-penggunainternet-di-indonesia-tembus-171-juta-jiwa

Firman. (18 August 2016). Literasi Indonesia yang Belum Merdeka. https://tirto.id/literasiindonesia-yang-belum-merdeka-bBJS

Mulyadi Chandra. (25 November 2014). 10 Peringkat Indonesia di Dunia. https://www.kompasiana.com/mulyady1688/54f934b0a333112c048b4a1a/10peringkat-indonesia-di-dunia

Iskandar Agung. 2010. Meningkatkan Kreativitas Pembelajaran Bagi Guru. Jakarta: Bestari Buana Murni

Mulyasa, E.2008. Standar Kompetensi dan sertifikasi Guru. Bandung : PT Remaja Rosdakarya

Hilman Kamaludin. (15 October 2019). 209 Anak Jadi Pasien RSJ Cisarua Jawa Barat Garagara Kecanduan Bermain Handphone. https://www.tribunnews.com/regional/2019/10/15/209-anak-jadi-pasien-rsj-cisaruajawa-barat-gara-gara-kecanduan-bermain-handphone 
Dewi Salma Prawiradilaga. (2013). Mozaik Teknologi Pendidikan E-learning. Yogyakarta: Kencana

Sutopo H.B. 2002. Metodologi Penelitian Kualitatif. Surakarta: UNS Press

Camelia. (6 March 2019). Tepergok Guru Main Ponsel di Kelas, Ekspresi Siswa Ini Bikin Ketawa Geli. https://www.liputan6.com/citizen6/read/3910678/tepergok-guru-mainponsel-di-kelas-ekspresi-siswa-ini-bikin-ketawa-geli

Wishnugroho Akbar. (8 March 2018). Ditegur saat Main HP di Kelas, Murid Pukul Guru dengan Kursi. https://www.cnnindonesia.com/nasional/20180308171331-12281519/ditegur-saat-main-hp-di-kelas-murid-pukul-guru-dengan-kursi

Roberto L Suson. (2019). Digital Citizenship in Education: Visioning Safety and Responsibilities in Digital World. International Journal of Trend in Scientific Research and Development, 3(4), 1637, e-ISSN: $2456-6470$

Teknologi. (14 January 2020). https://id.wikipedia.org/wiki/Teknologi

Rini dan Hanifati Intan. 2015. Etika Profesi dan Pengembangan, Pribadi. Palembang: Citrabooks Indonesia

Kasmir. 2005. Etika Customer Service. RajaGrafindo Persada. Jakarta.

Abd Haris. (2007).Pengantar Etika Islam. Sidoarjo: Al-Afkar

Indrajit, Richardus Eko. (2002). Buku Pintar Linux: Membangun Aplikasi e-Government. Jakarta:PT Elex Media Komputindo.

Teach with digital technologies. (25 September 2019). https://www.education.vic.gov.au/school/teachers/teachingresources/digital/Pages/teach .aspx 